Citation: Bozoklu Ç.P. (2018), Employer Brand Image Depending On Stakeholders' Material Value Tendency: Communication Market In Turkey, BMIJ, (2018), 6(3): 58-70 doi: http://dx.doi.org/10.15295/bmij.v6i3.318

\title{
EMPLOYER BRAND IMAGE DEPENDING ON STAKEHOLDERS' MATERIAL VALUE TENDENCY: COMMUNICATION MARKET IN TURKEY ${ }^{1}$
}

Çağla Pınar BOZOKLU²

\section{ABSTRACT}

According to branding and reputation literature, all stakeholders shares a common value system, which also leads developing similar perceptions towards corporates. As a value, materialism, especially effects the way that people mentally coding their environment and their lives. Preferences of consumers can differ from each other depending on how they judge the success depending on possessions or centralize the possessions in their life or are satisfied by owning them. The aim of this research is to test meaningful differences between employer brand images in terms of stakeholders' material value tendency. A questionnaire composed of Employer Brand Image and Material Value Scales was conducted to three primary stakeholder groups. Results reveal that employer brand image differs depending on the stakeholders' success-oriented and centrality-oriented material values for communication brands. The employer brand images of Vodafone and Turk Telekom that have the best and the worst reputation status in the market depending on being involved in a serious scandal, did not differ according to the stakeholders' material values, whereas the employer brand image of Turkcell which has an average position in the market, statistically differed.

Keywords: Employer Brand; Material Values, Ethical Values, Communication Market, Turkey JEL Codes: D12, D91, L25, L97, M31

\section{PAYDAŞLARIN MATERYALISTIK DEĞER EĞILIMINE GÖRE ISSVEREN MARKA IMAJI: TÜRKIYE'DE HABERLEŞME SEKTÖRÜ}

\section{ÖZ}

Markalaşma ve itibar literatürüne göre, tüm paydaşlar işletmelere yönelik benzer alglların oluşmasina yol açan, ortak bir değer systemini paylaşmaktadır. Değer olarak materyalizm özellikle hişilerin çevlerini ve kendi yaşamların zihinlerinde kodlama şeklini etkilemektedir. Tüketicilerin tercihleri, sahip oldukları varllklara göre başarıyı nasıl tanımladığına veya varlıkları hayatlarında konumlandırdıklarına veya onlara sahip olurken nasıl tatmin olduklarına göre değişebilmektedir. Bu araştırmanın amacı işveren marka imajındaki anlamlı değiş̧imin paydaşların materyalistik değer eğilimleri açısından tets edilmesidir. İşveren Marka İmajı ve Materyalistik Değerler Ölçeklerini içeren bir anket soru formu temel ü̧ paydaş grubuna uygulanmıştır. Sonuçlar, haberleşme marklaarı kapsamında işveren marka imajının paydaşların başarı ve merkeziyetçilik odaklı materyalistik değerlerine bağlı olarak değiş̧tiğini ortaya koymaktadır. Ciddi bir skandala karılşmış olmasına bağlı olarak, en iyi ve en kötü itibari konuma sahip olan, Vodafone and Turk Telekom'un işveren marka imajları paydaşların materyalistik değerlerine göre değişmezken; pazarda ortalama bir itibar konumuna sahip olan Turkcell'in işvereen marka imajı istatistiksel olarak değişmektedir.

Anahtar Kelimeler: İşveren Markalaşması, Materyalistik Değerler, Etik Değerler, Haberleşme Sektörü, Türkiye JEL Codes: D12, D91, L25, L97, M31

\footnotetext{
${ }^{1} \mathrm{Bu}$ çalışma "Business and Organization Research Conference-BOR 2018" adlı kongrede yayınlanmıştır.

${ }^{2}$ Dr. Öğr.Üyesi, Başkent Üniversitesi, cpbozoklu@ baskent.edu.tr https://orcid.org/0000-0002-4147-9519
} 


\section{INTRODUCTION}

In the literature, although there are various definitions of "materialism" or "materialistic" terms, they have a common focal point. All authors agree with the concepts of spending, possession and material interest. They present a great body of literature based on materialism that reveal causes and consequences of materialism, characteristics of materialists, and moral considerations (Belk, 1983; Fournier, 1991).

Belk (1984) suggested that one's possessions are a major contributor to and reflection of his/her identity. It is also meant that materialism is a value, which triggers consumers to assert, complete or attain their ideal selves. In return, consumers tend to prefer brands that reflect similar identity within the context of their image. Sharing common values with stakeholders such as customers may facilitate the integration and strengthening of brand image and then, corporate reputation as well.

In the image development process, corporates primarily focus on their identity which they can control by the reason of image is ultimately formed in the mind of the receiver based on its identity (Meenaghan, 1995). Therefore, a strategic approach is necessary for the linkage of identity and specific brand values. Creating a brand's association is a long-term process, and should be considered as an investment (Meenaghan, 1995).

On the other hand, materialism is a value which has an influence on consumers' brand preferences and brand perceptions. It is found negatively correlated with people's higher ethical standards (Muncy and Eastman, 1998). Despite, that kind of relationship could not be generalized because the direction of causality is not known, the possibility that causing one to become more materialistic may also cause him/her to have lower ethical standards does exist. This relationship can cause a differentiation on the judgements of brand image that stakeholders give priority process in their minds.

Thus, it is examined whether there is any difference between the stakeholders who have material tendency or anti-material tendency in terms of the employer brand image. As a starting point, existing literature on the relationship between materialism and brand image is summarized, which is subsequently tested depending on the research hypothesis.

\section{THE RELATIONSHIP BETWEEN MATERIALISM AND BRAND IMAGE}

Materialism can be thought as a cluster of related traits, attitudes and values focusing not only on possessions, but also on guiding the selection of events and things. Highly materialistic individuals devote more energy to activities involving products and brands (Browne and Kaldenberg, 1997: 33). 
Especially, they tend to value items that are consumed publicly (Richins, 1994b) by reason of they also interest in impression management.

Consumers vary in their tendency to perceive, to prefer and to possess depending on their particular self-schemas, and this differentiation causes to various attitudes and behaviors toward brands. Consumers who prefer to pick up high-priced apparel strive to satisfy expression of their identitiy (Kaiser, 1990; O’Shaughnessey 1987), self-image (Vreeman and Morganosky, 1986) and needs (Kamineni, 2005). For example, status consumption was found to have a significant positive relationship with materialism among Malaysian students (Heaney et al., 2005). Similarly, the results of Nga, Yong and Sellapan's (2011) study shows that materialism mediates image consciousness and compulsive spending. Consumers who are highly materialistic may value the possession of luxury brands (Bearden, Netemeyer, Teel, 1989; Richins, 1994a). Individuals worried with social acceptance with reference groups may appreciate socially visible and expensive possessions (Vigneron and Johnson, 2004). Moreover, it is found that in a competitive environment, the acquirement of social status via material possessions may cause misuse of credit card and splurge spending (Pirog and Roberts, 2007; Fitzmaurice, 2008).

According to Richins and Dawson (1992), ordinary consumers' perception of materialism appears in a multidimensional structure that are classified as acquisition of centrality, acquisition as the pursuit of happiness, possession-defined success. Briefly, preferences of consumers can differ from each other according to how much they judge the success of others and their selves depending on their possessions or centralize the possessions in their life or are satisfied by owning possessions.

The dimension of acquisition centrality considers the materialists who locate possessions and their acquisition at the center of their lives. It is accepted as a lifestyle which is an also goal and serves as an asset of plan. The dimension of acquisition as the pursuit of happiness posits that materialists view possessions as essential to their satisfaction and well-being in life. Richins and Dawson (1992, p. 304) also emphasize that "While most individuals are probably involved to some extent in the pursuit of happiness, it is the pursuit of happiness through acquisition rather than through other means (such as personal relationships, experiences, or achievements) that distinguishes materialism". The dimension of possession-defined success assumes that materialists approach to success depending the number and quality of possessions.

As a value which has an influence on consumers' brand preferences and brand perceptions, materialism is a widely accepted structural body for the marketing, psychology and consumer researches (Sprott, Czellar and Spangenberg, 2009; Kilbourne and Pickett, 2008; Rindfleisch, 
Burroughs and Wong, 2008; Banerjee and McKeage, 1994; Freling and others, 2011; Kolodinsky and others, 2010; Urien and Kilbourne, 2011).

Brand image may be identified as "the set of beliefs held about a particular brand" (Kotler, 1988, p. 197) or "a set of associations, usually organized in some meaningful way" (Aaker, 1992, pp. 109-10). In the image development process, a company will focus on its identity. "In order to be successful, images and symbols must relate to, and indeed, exploit, the needs, values and life-styles of consumers in such a way that the meanings involved give added values, and differentiate the brand from other brands" (Broadbent and Cooper, 1987, p. 3). According to brand image and reputation literature, all stakeholders shares a common value system, which also leads sharing similar perceptions towards corporates. (Walsh and Beatty, 2007).

Ambler and Barrow (1996: 187) are the first researchers who coined the employer branding and identified as "the package of functional, economic and psychological benefits provided by employment". Researchers like Hart and Murphy (1998) and Ind (1997, 1998) suggest that stronger corporate brands able to recruit and retain in their hands the best employees. This idea has been developed as the concept of employer brand image in time (i.e. Ambler and Barrow, 1996; Backhaus and Tikko, 2004; Berthon et al. 2005, Carrington, 2007; Moroko and Uncles, 2008). Employer branding not only brings competitive differentiation in terms of brand awareness and brand preference, but also contributes to appeal most competent employees in the markets. A stronger employer brand can be also implicitly associated with the higher ethical standards, considered as distinctive functional, economic and psychological benefits for the company's employees. In this way employer brand image can provide a halo effect on consumer judgments, such as the positively evaluation of brand image (Klein and Dawar, 2004).

\section{METHOD}

The aim of this research is to analyze is there any meaningful differences between stakeholders' perception of employer brand image and customer relationship image in terms of their material value tendency.

Therefore, the hypothesis is:

$H_{0}=$ There is no statistically meaningful difference in employer brand image in terms of stakeholders' material value tendency.

Three facets as Material Values, Corporate Reputation and Demographics form the questionnaire. The Material Values Scale shortened to 9 five-point Likert items by Richins (2004) in due to take up less space on a survey instrument. Each of three subscales (success, centrality and 
happiness) consists of three items. The results of her research indicated that nine-item version carries better psychometric properties than the six and three item scales. Good Employer subscale of Corporate Reputation Scale developed by G. Walsh and S. Beatty (2007) was conducted to internal and external stakeholders. It is also measured by 5 point Likert. Six demographical items that are not only consist of gender, age, marital status, education, and income level questions; but also working place, job experience years and their stakeholder group questions were added to scale.

The employer brands as Türk Telekom, Vodafone and Turkcell, operating in communication sector, are chosen as decision unit due to their unique characteristics.

\section{FINDINGS}

At the first stage of the analyses, Kolmogorov Smirnov test was done to test whether Likert items are distributing normally. According to result data is not distributing normally $\left(p^{\text {Kolmogorov }} \leq 0.001, p^{\text {Shapiro }} \leq 0.001\right)$. Therefore, it was decided to apply non-parametric tests.

The findings of reliability test presented in Table 1. All dimensions of Material Values Scale (success, centrality and happiness) and Employer Brand Image are found greater than 0.70 (Nunnally, 1978).

Secondarily, exploratory factor analyses were conducted for the validity of scales. Principal component extraction with Varimax rotation was applied to each sub-scale's items. The Kaiser-MeyerOlkin (KMO) value for Success sub-scale was 0.693 and Bartlett's test was significant at the 0.00 level. These results demonstrate the factorability of the data matrices (Hair et al., 1998). The criterion for the significance of factor loadings was set at 0.45 , and all items showed high cross loadings $(>0.40)$ ranging from .80 to.83. Item 3 of Material Values Scale has the highest factor loading. The factor solution accounted for approximately $67.3 \%$ of the total variance.

Table 1: Scale Reliability

\begin{tabular}{lll}
\hline Scale & Dimension & Cronbach Alpha \\
\hline Material Values Scale & Success & 0.794 \\
& Centrality & 0.809 \\
& Happiness & 0.798 \\
\hline Corporate Reputation Scale & Employer Brand Image & 0.765 \\
\hline
\end{tabular}

The Kaiser-Meyer-Olkin (KMO) value for Centrality sub-scale was 0.689 and Bartlett's test was significant at the 0.00 level. All items showed high cross loadings (> 0.40) ranging from .81 to.89. 
Item 2 of Material Values Scale has the highest factor loading. The factor solution accounted for approximately $72.3 \%$ of the total variance.

The Kaiser-Meyer-Olkin (KMO) value for Happiness sub-scale was 0.669 and Bartlett's test was significant at the 0.00 level. All items showed high cross loadings (>0.40) ranging from .76 to.88. Item 8 of Material Values Scale has the highest factor loading. The factor solution accounted for approximately $71.2 \%$ of the total variance.

The Kaiser-Meyer-Olkin (KMO) value for Employer Brand Image sub-scale was 0.868 and Bartlett's test was significant at the 0.00 level. All items showed high cross loadings $(>0.40)$ ranging from .52 to. 85 . Item 8 of Corporate Reputation Scale has the highest factor loading. The factor solution accounted for approximately $54.4 \%$ of the total variance.

\subsection{Differences in Employer Brand Image in Terms of Stakeholders' Material Value Tendency}

As testing the research hypothesis, mean values of Success, Centrality and Happiness subscales are measured at first $\left(\bar{X}^{\text {success }}=2.9 ; \bar{X}^{\text {Centrality }}=3.01 ; \bar{X}^{\text {Happiness }}=3.27\right)$. The observed values greater than or equal to them are identified as material tendency, whereas the observed values less than them are labeled as anti-material tendency. Secondarily, Mann Whitney U Tests are done to determine whether there is any meaningful difference in employer brand image in terms of stakeholders' material value tendency.

According to the findings, two items of employer image differ in terms of success-oriented material values. As it is seen in Table 2, stakeholders owned anti-material value tendency (successoriented) have thought that their company "maintains high standards in the way that it treats people" and that it is "managed-well" ( $p^{E 6}=.042, R_{\text {anti-material }}>R_{\text {material }} ; p^{E 7}=.022, R_{\text {anti-material }}>$ $R_{\text {material }}$

Table 2: Differences in Employer Brand Image in Terms of Stakeholders' Success-Oriented Material Value Tendency

\begin{tabular}{|c|c|c|c|c|c|c|}
\hline $\begin{array}{l}\text { Brand } \\
\text { Image }\end{array}$ & Item & $\begin{array}{l}\text { Value } \\
\text { Tendency }\end{array}$ & $\mathbf{N}$ & $\mathbf{R}$ & $\mathbf{U}$ & $\mathbf{p}$ \\
\hline Employer & 6.Company seems to maintain high & Material & 214 & 221.72 & 24444.00 & .042 \\
\hline \multirow[t]{4}{*}{ Image } & $\begin{array}{l}\text { standards in the way that it treats } \\
\text { people. }\end{array}$ & $\begin{array}{r}\text { Anti-material } \\
\text { Total }\end{array}$ & $\begin{array}{l}255 \\
469\end{array}$ & 246.14 & & \\
\hline & 7.Company seems to be well- & Material & 214 & 219.99 & 22072.00 & .022 \\
\hline & managed. & Anti-material & 255 & 247.60 & & \\
\hline & & Total & 469 & & & \\
\hline
\end{tabular}


Within the context of centrality-oriented material values, stakeholders owned anti-material value tendency (centrality-oriented) think that their company "a good company to work for" in terms of employer image (Table 3) $\left(p^{E 1}=.030, R_{\text {anti-material }}>R_{\text {material }}\right)$.

Table 3: Differences In Employer Brand Image In Terms Of Stakeholders' Centrality-Oriented Material Value Tendency

\begin{tabular}{|c|c|c|c|c|c|c|}
\hline Brand & Item & Value & $\mathbf{N}$ & $\mathbf{R}$ & $\mathbf{U}$ & $\mathbf{p}$ \\
\hline Image & & Tendency & & & & \\
\hline Employer & 1.Company looks like a good & Material & 245 & 222.48 & 24371.50 & .030 \\
\hline \multirow[t]{2}{*}{ Image } & company to work for. & Anti-material & 224 & 248.70 & & \\
\hline & & Total & 469 & & & \\
\hline
\end{tabular}

On the other hand, employer image does not differ in terms of happiness-oriented material values.

\subsection{Differences in Employer Brand Images of Corporates in terms of Stakeholders' Material} Value Tendency

\section{i. Türk Telekom}

Türk Telekom's ownership structure consist of \%15 free float, $\% 25$ Republic of TurkeyMinistry of Treasury and Finance, \%5 Turkish Wealth Fund and \%55 Ojer Telekomunikasyon A.Ş.. According to Official Gazette published on 5 February 2017, Council of Ministers agreed to transfer $6.68 \%$ (5\% B Group shares and $1.68 \%$ D Group shares) of the shares belonging to Republic of Turkey Ministry of Treasury and Finance to the Turkish Wealth Fund (Turk Telekom, 2018). On 29 August 2018, Turk Telekom stated that:

“The takeover of Ojer Telekomünikasyon A.Ş.’s [OTAŞ] 55 percent shares in our company, Türk Telekomünikasyon A.Ş. [Türk Telekom] by a special purpose vehicle [SPV] which the creditor banks of OTAŞ would be shareholders, has been approved by the Treasury and Finance Ministry." According to Hürriyet Daily News' article entitled “Transfer of Türk Telekom's majority stake to banks approved by Turkish government", after two years of negotiations regarding the failed repayments, creditor banks, including Akbank, Garanti and İşbank, applied to the Competition Board to take over the shares. Akbank, Garanti and İşbank respectively had granted a loan of nearly $\$ 1.5$ billion, \$1 billion and \$500 million (Hürriyet Daily News, 2018).

Depending on this information, it is suggested that the brand image of Turk Telekom should have been damaged in the eye of stakeholders especially who have relatively strict ethical values.

Mann Whitney U Tests are done to determine whether there is any meaningful difference in 
Turk Telekom's employer brand image in terms of stakeholders' material value tendency.

According to findings, Turk Telekom's employer image have not differed in terms of stakeholders' success-oriented, centrality-oriented and happiness-oriented material values ( $p>.05)$.

\section{ii. Turkcell}

Turkcell is a private sector business and its founding shareholders are Sonera holding, formerly known as Tlecem Finland Ltd. and currently owned by TeliaSonera, Çukurova Group and MV Holding. Çukurova Group and MV Holding are the Turkish investments whereas TeliaSonera is a multinational business which is formed with the merge of a Finnish telecommunication provider Sonera and Swedish telecommunication operator Telia. Turkcell shares are listed on the Borsa Istanbul and on the New York Stock Exchange as the American Depositary Shares (Turkcell, 2018).

In the year of 2016, an employee of Ensar Vakfi, has a sponsorship agreement with Turkcell, was found guilty on children abuse and then he had charged to 508 years prison sentence. As the spread of the news, a boycott for cutting off Turkcell phone lines had been organized among customers in the same year. On the other hand, no damaging news had been reported about Turkcell since those days. Depending on that, it is suggested that Turkcell has been endeavoring to recover its brand image in the eye of its stakeholders.

Mann Whitney U Tests are done to determine whether there is any meaningful difference in Turkcell's employer brand image in terms of stakeholders' material value tendency.

According to Table 5, stakeholders owned anti-material value tendency (success-oriented) think that Turkcell quite "maintains high standards in the way that it treats people" and it is managedwell compared to others $\left(p^{E 6}=.003, R_{\text {anti-material }}>R_{\text {material }} ; p^{E 7}=.005, R_{\text {anti-material }}>\right.$ $\left.R_{\text {material }}\right)$.

Table 5: Differences in Turkcell's Employer Brand Image in Terms of Stakeholders' SuccessOriented Material Values

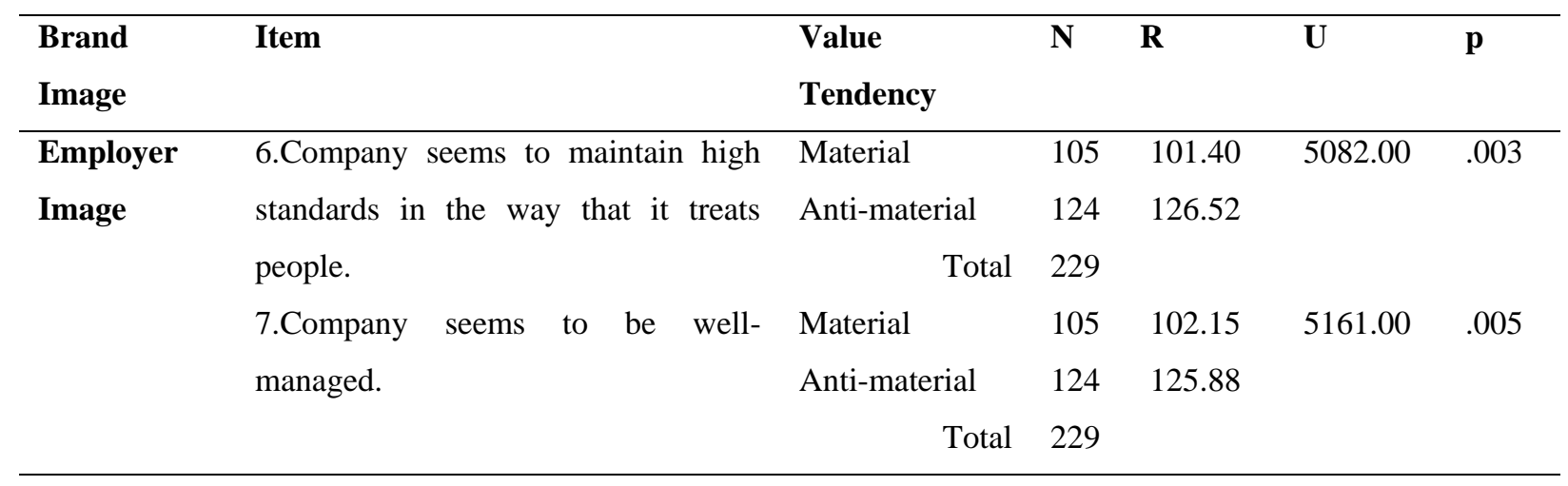


As seen in Table 6, stakeholders owned anti-material value tendency (centrality-oriented) think that Turkcell "looks like a good company to work for" compared to materialistic ones in terms of employer image. $\left(p^{E 1}=.022, R_{\text {anti-material }}>R_{\text {material }}\right)$.

Table 6: Differences In Turkcell's Employer Brand Image In Terms Of Stakeholders' Centrality-

Oriented Material Values

\begin{tabular}{|c|c|c|c|c|c|c|}
\hline $\begin{array}{l}\text { Brand } \\
\text { Image }\end{array}$ & Item & $\begin{array}{l}\text { Value } \\
\text { Tendency }\end{array}$ & $\mathbf{N}$ & $\mathbf{R}$ & $\mathbf{U}$ & $\mathbf{p}$ \\
\hline $\begin{array}{l}\text { Employer } \\
\text { Image }\end{array}$ & $\begin{array}{l}\text { 1. Company looks like a good } \\
\text { company to work for. }\end{array}$ & $\begin{array}{l}\text { Material } \\
\text { Anti-material } \\
\qquad \text { Total }\end{array}$ & $\begin{array}{l}123 \\
106 \\
229\end{array}$ & $\begin{array}{l}106.05 \\
125.38\end{array}$ & 5418.50 & .022 \\
\hline
\end{tabular}

According to findings, there is no meaningful difference for Turkcell's employer image in terms of stakeholders' happiness-oriented material values.

\section{iii. Vodafone}

Vodafone Group Plc's shares composed of non-institutional ownership in majority (89.91\%). $10.9 \%$ of shares are owned by Institutional Holders such as Bank of America Corporation (\%1.02), Fisher Asset Management, LLC (0.97\%), Price (T. Rowe) Associates Inc. (0.71\%), Hotchkis \& Wiley Capital Management, (0.62\%), Invesco Ltd. (0.49\%), Morgan Stanley (0.45\%), Federated Investors, Inc. $(0.38 \%)$, Wells Fargo \& Company (0.30\%), Dimensional Fund Advisors (0.28\%) and Raymond James \& Associates, Inc. (0.25\%) (Yahoo Finance, 2018).

There is no evidence on Vodafone has involved in a scandal in Turkey press. It has received various kinds of complaints from its customers about the applications (e.g. şikayetvar, 2018) but yet it has been consistently protecting its brand image and reputation.

Mann Whitney U Tests are done to determine whether there is any meaningful difference in Vodafone's employer brand image in terms of stakeholders' material value tendency.

According to findings, employer image of Vodafone does not differ in terms of successoriented, centrality-oriented and happiness-oriented material values ( $\mathrm{p}>.05)$.

\section{CONCLUSION}

Materialism is a concept which is not only contributes to consumers' identity but also reflects it to the social environment by means of possession preferences. In the case of consumers who own anti-materialistic value tendency has stricter ethical values, they will distinctively evaluate the brand related issues. However, that kind of relationship could not be generalized because the direction of causality has not known. This is the limitation of this research but yet, the possibility that causing one to become more materialistic may also cause him/her to have lower ethical standards does exist. 
Depending on that assumption, the research hypothesis- there is no difference in employer brand image in terms of stakeholders' materialistic value tendency- was tested for communication market. As suggested, findings reveal that materialistic tendency has an influence on the perception of employer brand image.

As it is seen in the results of exploratory factor analyses, factor solutions accounted insufficient for total variance. According that, materialism does not sufficient for the exploratory level of employer brand image. Other variables influenced on brand image should be also examined and tested. On the other hand, the results of Mann Whitney $U$ tests present evidence on that the perception of employer brand image differs depending on the stakeholders' success-oriented and centrality-oriented material values for communication brands. "Maintaining high standards in the way that company treats people", "Being managed-well", and "Looking like a good place to work" are the significant factors for the anti-materialistic consumers. As Muncy and Eastman (1998) tested and then found, the factor of "Maintaining high standards" can be quite related with the anti-materialists' ethical standards. They may essentially prefer the corporate brands, which develop moral codes for its employees as its identity. In addition, the factor of "Looking like a good place to work" bears a striking resemblance to the employer brand definition coined by Lloyd (2002). He stated that employer branding is the "sum of a company's efforts to communicate to existing and prospective staff that it is a desirable place to work". This resemblance also affirms materialistic tendency has an influence on the perception of employer brand image.

According to the firm-based results, the employer brand image of Turkcell that had gone through a serious scandal in 2016, perceived differently by its stakeholders depending on their successoriented and centrality-oriented material values. There are only three brands -Turkcell, Turk Telekom and Vodafone- in the communication market in Turkey. They have different status depending on their reputations by reason whether they had involved any scandals. After Turk Telekom's scandal which it lost its shares to the banks in proportion to the loan they had granted, according to the agreement facilitated by the Turkish government and related laws, the reliability and credibility of it may be damaged heavily in the eye of its stakeholders. Turkcell had also indirectly involved in a disgraceful offense but it seems like recovering its wounds during last years. On the other side, Vodafone, foreign investment in a national market, had never involves in a scandal. The employer brand image of marginal ones, Vodafone and Turk Telekom, did not differ depending on the stakeholders' material values, whereas the employer brand image of Turkcell statistically differed. Heavily damaged reputations such as Turk Telekom, can trigger negative brand evaluations in the eye of stakeholders without noticing their ethical or material values. As the literature reveals, having a positive reputation 
will protect the organization from the occasional glitch, but a consistent difference between the internal identity and external image may create serious damage. The emergence of gaps between stakeholders' perceptions of a corporate brand has to be considered as a threat (Aaker, 1996; de Chernatony, 1999; Bickerton, 2000; Harris and de Chernatony, 2001). On the other hand, brand evaluations without noticing ethical or material values may be also realized for well-behaved brands such as Vodafone. The employer brand image of Turkcell, as in the middle, may be comparatively and unintentionally processed in the consumer mind depending on their material value tendency.

Following the anti-globalization movement, stakeholder activism, an ideology and/or a lifestyle which reflects a climate of defiance toward businesses has seep into society. Depending on this wind of change, businesses and academics should examine in detail cynics, anti-materialists, simplifiers, etc. who have negative attitudes towards businesses. Their needs and motivators can be adapted as a marketing strategy for a more sustainable life. Within the context of future researches, mediator effects of functional and symbolic utilities can be also considered in the same model for explaining their roles on employer brand image among anti-materialists. 


\section{REFERENCES}

Aaker, D. A. (1992). The value of brand equity. Journal of business strategy, 13(4), 27-32.

Aaker, D.A. (1996). Building strong brands. New York: The Free Press.

Ambler, T., and Barrow, S. (1996). The employer brand. Journal of brand management, 4(3), 185-206.

Backhaus, K. and Tikoo, S. (2004). Conceptualizing and researching employer branding. Career Development International 9(4/5), 501-517.

Banerjee, B., and McKeage, K. (1994). How green is my value: exploring the relationship between environmentalism and materialism. ACR North American Advances.

Bearden, W., Netemeyer, R. G. and Teel, J. E. (1989) 'Measurement of consumer susceptibility to interpersonal influence', Journal of Consumer Research, Vol. 15, March, pp. 473-481.

Belk, R. W. (1983). Worldly possessions: Issues and criticisms. ACR North American Advances.

Belk, R. W. (1984). Three scales to measure constructs related to materialism: Reliability, validity, and relationships to measures of happiness. ACR North American Advances.

Berthon, P., Ewing, M. and Hah, L. (2005). Captivating company: dimensions of attractiveness in employer branding. International Journal of Advertising 24(2), 151-172.

Bickerton, D. (2000). Corporate reputation versus corporate branding: the realist debate. Corporate Communications 1 , $42-48$.

Broadbent, K., and Cooper, P. (1987). Research is good for you. Marketing Intelligence \& Planning, 5(1), 3-9.

Browne, B. A., and Kaldenberg, D. O. (1997). Conceptualizing self-monitoring: Links to materialism and product involvement. Journal of Consumer Marketing, 14(1), 31-44.

Carrington, L. (2007). Designs on the dotted line People Management Magazine (18 October), 36 -39.

de Chernatony, L. (1999). Brand management through narrowing the gap between brand identity and brand reputation. Journal of Marketing Management 15(1-3), 157-180.

Fitzmaurice, J. (2008), "Splurge purchases and materialism”, Journal of Consumer Marketing, Vol. 25 No. 6, pp. $332-8$.

Fournier, S. (1991). Meaning-based framework for the study of consumer-object relations. ACR North American Advances.

Freling, T. H., Crosno, J. L., and Henard, D. H. (2011). Brand personality appeal: conceptualization and empirical validation. Journal of the Academy of Marketing Science, 39(3), 392-406.

Hair, JF, Anderson RE, Tatham RL, Black WC. Multivariate data analysis. New Jersey: Prentice-Hall; 1998.

Hart, S. and Murphy, J. (1998). Brands: The New Wealth Creators. Basingstoke: Macmillan Business.

Harris, F. and de Chernatony, L. (2001). Corporate branding and corporate brand performance. European Journal of Marketing 35(3/4), 441-456.

Heaney, J., Goldsmith, R.E. and Wan Jusoh, W.J. (2005), "Status consumption among Malaysian consumers: exploring its relationship with materialism and attention to social comparison information", Journal of International Consumer Marketing, Vol. 17 No. 4, pp. 83-98.

Hürriyet Daily News, (2018). Transfer of Türk Telekom's majority stake to banks approved by Turkish gov't. 29 August ,2018. Erişim Tarihi: 27.09.2018 http://www.hurriyetdailynews.com/transfer-of-turk-telekoms-majority-stake-tobanks-approved-by-turkish-govt-136250

Ind, N. (1997). The Corporate Brand. Basingstoke: Macmillan Business.

Ind, N. (1998). An integrated approach to corporate branding. The Journal of Brand Management 5(5), 323-329.

Kaiser, S. B. (1990). The social psychology of clothing: Symbolic appearances in context.

Kamineni, R. (2005). Influence of materialism, gender and nationality on consumer brand perceptions. Journal of Targeting, Measurement and Analysis for Marketing, 14(1), 25-32.

Kilbourne, W., and Pickett, G. (2008). How materialism affects environmental beliefs, concern, and environmentally responsible behavior. Journal of Business Research, 61(9), 885-893.

Klein, J., and Dawar, N. (2004), “Corporate social responsibility and consumers' attributions and brand evaluations in a product-harm crisis”, International Journal of Research in Marketing, Vol. 21 No. 3, pp. 203-217.

Kolodinsky, R. W., Madden, T. M., Zisk, D. S., and Henkel, E. T. (2010). Attitudes about corporate social responsibility: Business student predictors. Journal of Business Ethics, 91(2), 167-181.

Kotler, P. (1988), Marketing Management: Analysis, Planning and Control, Prentice-Hall, Englewood Cliffs, NJ.

Lloyd, S. (2002). Branding from the inside out. BRW 2(10), 64-66.

Moroko, L. and Uncles, M. (2008). Characteristics of successful employer brands. Journal of Brand Management 16(3), $160-175$.

Meenaghan, T. (1995). The role of advertising in brand image development. Journal of Product \& Brand Management, 4(4), 23-34.

Muncy, J. A., and Eastman, J. K. (1998). Materialism and consumer ethics: An exploratory study. Journal of Business Ethics, 17(2), 137-145.

Nga, J. K., Yong, L. H., and Sellappan, R. (2011). The influence of image consciousness, materialism and compulsive spending on credit card usage intentions among youth. Young Consumers, 12(3), 243-253. 
Nunnaly, J. (1978). Psychometric theory. New York: McGraw-Hill.

O'Shaughnessy, J. (1987), Why People Buy, Oxford University Press, New York, NY.

Pirog, S.F. II and Roberts, J.A. (2007), "Personality and credit card misuse among college students: the mediating role of impulsiveness", Journal of Marketing Theory and Practice, Vol. 15 No. 1, pp. 65-77.

Richins, M. L., and Dawson, S. (1992). A consumer values orientation for materialism and its measurement: Scale development and validation. Journal of consumer research, 19(3), 303-316.

Richins, M. L. (1994a) 'Valuing things: The public and private meanings of possessions', Journal of Consumer Research, Vol. 21, December, pp. 504-521.

Richins, M. L. (1994b) 'Special possessions and the expression of material values', Journal of Consumer Research, Vol. 21, December, pp. 522-533.

Richins, M. L. (2004). The material values scale: Measurement properties and development of a short form. Journal of consumer Research, 31(1), 209-219.

Rindfleisch, A., Burroughs, J. E., and Wong, N. (2008). The safety of objects: Materialism, existential insecurity, and brand connection. Journal of Consumer Research, 36(1), 1-16.

Sprott, D., Czellar, S., and Spangenberg, E. (2009). The importance of a general measure of brand engagement on market behavior: Development and validation of a scale. Journal of Marketing Research, 46(1), 92-104.

Turkcell, (2018). Ortaklık Yapısı. Erişim Tarihi: 29.09. 2018 Erişim Adresi: https://www.turkcell.com.tr/en/aboutus/investor-relations/corporate-governance/shareholder-structure.

Türk Telekom, (2018). Ortaklık Yapısı. Erişim tarihi: 29.09.2018. Erişim adresi http://www.ttyatirimciiliskileri.com.tr/enus/turk-telekom-group/investing-in-turk-telekom/pages/ownership-structure.aspx

Urien, B., and Kilbourne, W. (2011). Generativity and self-enhancement values in eco-friendly behavioral intentions and environmentally responsible consumption behavior. Psychology \& Marketing, 28(1), 69-90.

Vigneron, F., and Johnson, L. W. (2004). Measuring perceptions of brand luxury. Journal of brand management, 11(6), 484-506.

Vreeman, A. L., and Morganosky, M. A. (1986). Consumer Involvement Related to Apparel Purchase Behavior. ACR North American Advances.

Walsh G., Beatty, S. (2007). Customer-based corporate reputation of a service firm: scale development and validation. Journal of Marketing Science (35): 127-145.

Yahoo Finance (2018). Vodafone Group Plc shareholder structure. Erişim Tarihi: 29.09. 2018. Erişim adresi: https://finance.yahoo.com/quote/VOD/holders/ 